\title{
The Controversy over the Buddhas of Bamiyan
}

\section{Pierre Centlivres}

\section{(2) OpenEdition}

\section{Journals}

Electronic version

URL: http://journals.openedition.org/samaj/992

DOI: 10.4000/samaj.992

ISSN: $1960-6060$

\section{Publisher}

Association pour la recherche sur l'Asie du Sud (ARAS)

\section{Electronic reference}

Pierre Centlivres, «The Controversy over the Buddhas of Bamiyan », South Asia Multidisciplinary Academic Journal [Online], 2 | 2008, Online since 31 December 2008, connection on 10 December 2020. URL : http://journals.openedition.org/samaj/992 ; DOI : https://doi.org/10.4000/samaj.992

This text was automatically generated on 10 December 2020.

\section{(c) (i) (9)}

This work is licensed under a Creative Commons Attribution-NonCommercial-NoDerivatives 4.0 International License. 


\title{
The Controversy over the Buddhas of Bamiyan
}

\author{
Pierre Centlivres
}

\section{Introduction: From Artemis temple at Ephesus to Bamiyan}

In 1840, La Revue des Deux Mondes published an amazing and satirical poem titled Érostrate au temple d'Ephèse. ${ }^{1}$ Written by the then well-known poet Auguste Barbier (1805-1882), it was meant, according to a contemporary critic, to 'castigate the ambitious mediocrity that stops at nothing even at crime, when ambition and celebrity are at stake'. ${ }^{2}$ My idea is precisely to start with the famous iconoclast Erostrate and with the destruction of the Temple of Artemis at Ephesus in $356 \mathrm{BC}$ as a paradigmatic way to speak about the destruction of the Buddhas in Bamiyan (Afghanistan), some 2,357 years later. ${ }^{3}$

Barbier does not put the monument itself at the centre of the poem, but he definitely hints at the very person of the iconoclast, fascinated by the sacrilege and the outrage he was to commit, a sacrilege that future generations will recall tirelessly. In the poem, the outrage consists first in an offence to the deities, or rather to personified abstractions, such as Piety and Beauty. It is also, according to the poem, an insult to the whole of mankind. Erostrate himself described his monstrous act as a sacrifice to the 'consuming Death', also a personified entity. Speaking of the sacrifice he was offering, the iconoclast declared: 'it is more than hundred bulls with golden horns'; it was meant to escape the sense of annihilation that oblivion brings about. Yet, the victim of the sacrifice was not clearly referred to: it could be the monument itself, burned down by Erostrate, or Erostrate himself. The ones offended by this act of iconoclasm, beyond the temple and its deity, are not clearly discernible either: the deified Beauty or 'ignorant peoples'? 'false pontiffs'? 'the city'?, to quote the very words of Barbier.

The case of the Buddhas of Bamiyan, whose destruction was ordered by the Taliban in 2001, shows intriguing similarities with the destruction of Artemis Temple: the eradication of a monument, sacred as well as emblematic and belonging to the cultural 
heritage, an attack against the Piety and the Beauty, a religious offence and an outrage to an art monument; in other words a sacrifice in all its ambiguous meanings. A similar uncertainty characterizes as well the identification of the victims: are they people in general, abstract deities, specific communities? Are they Buddhists in South and Southeast Asia? Inhabitants of central Afghanistan? Or virtual communities, such as western art lovers? International Organisations (UNESCO, etc.)? Or is the whole humanity the real victim? It is far from evident as will be discussed in this article.

The 2001 destruction in Bamiyan is, by far, the most spectacular attack against the historical and cultural heritage of Afghanistan ever committed during the recent period of turmoil the country has passed through-a period that began with the Communist Coup of April 1978 and is still not over. It is also unique for the worldwide mobilisation it aroused, though it is, alas, not the only damage inflicted to archaeological remains in Afghanistan. If, at least intentionally, the Communists did not destroy any religious monuments when in power in Kabul, it remains that, unfortunately, the old city of Herat and the neighbouring monuments, for instance, suffered a lot from the fighting. The remaining minaret of the Gôwhar-Shâd Mosque, built during the Timurid period, was almost entirely destroyed by the Russian artillery fire. Yet, the communist regime was rather anxious to show, especially to the international community, its concern for the preservation of the historical heritage. But nothing happened in Afghanistan which could be compared to the revolutionary iconoclasm that destroyed Buddhist temples and images in Mongolia, Tibet and other places in Maoist China during the Great Cultural Revolution, so as to take away their sacred aura and to prove that their religious or magical power were non-existent.

But on the mujahidin side, the situation sharply differed. The Buddhist archaeological site of Hadda (south-east of Afghanistan) was entirely devastated by some Islamic groups who had been 'pushed by the mullahs to destroy the pagan idols' (Dupaigne 2007: 40). Nothing remains today of this extraordinary site, of its sanctuaries, stupas and stucco figurines, except perhaps for a few of them smuggled, now in Peshawar or elsewhere. A mosque made in cement was even built in Hadda in 2002 at the very location of Mullah of Hadda's birth, the 'mad mullah' who had called for jihad against the British in the late $19^{\text {th }}$ century. ${ }^{4}$ Though no Buddhists live in Afghanistan, what was at stake here-and very much like what happened in Mongolia or in China-, was the eradication of objects or monuments considered subjects of illusory beliefs and their replacement by the 'True Word'. This, somehow, foreshadowed the Taliban's 'puritan' iconoclasm.

\section{Mullah Omar's decree}

On 26 February, 2001, and after having consulted a college of ulema, Mullah Omar, the leader of the Taliban, issued a decree ordering the elimination of all non-Islamic statues and sanctuaries from Afghanistan. A kind of jihad was launched against the two Buddhas, hewn into the cliff of Bamiyan. 'Our soldiers are working hard; they are using all available arms against the Buddhas', said the Taliban's spokesman. ${ }^{5}$ Rocket and tank shells were brought into help, and the destruction was completed with dynamite. 'It took us twenty days; it was a trying work', he insisted. On 14 March, the Taliban made a public announcement to inform that the giant figures of the Buddhas of Bamiyan and the statues kept in the Afghan National Museum in Kabul had all been destroyed. 
To the Muslim leaders of neighbouring countries, alarmed by the possible consequences of such an inordinate action, the Mullah answered: 'How could we justify, at the time of the Last Judgement, having left these impurities on Afghan soil?' (Lafrance 2001: 19). The too long presence of the statues in a Muslim country was, according to him, a stain, a major impurity that had to be gotten rid of. A twofold sacrifice was necessary: first, the purifying sacrifice of the statues (decided by the 26 February decree) and then, the expiatory sacrifice of one hundred cows throughout the country, including twelve in the former presidential palace (ordered on $15 \mathrm{March}$ ). In compliance with religious dictates, the meat was to be given to the poor; a sacrifice that strangely echoes the "hundred bulls with gilding horns' mentioned in Auguste Barbier's poem.

Yet, the victory over the Buddhas could only be won if there were witnesses. This is why journalists, after witnessing the emptiness of the Kabul Museum, were flown to Bamiyan on 26 March to see with their own eyes the gaping openness of the niches, deep into the cliff, where the statues used to be. Prior to that, on the $19^{\text {th }}$ March, the Taliban had agreed for this one occasion only to let al-Jazira's cameramen witness the final phase of the sacrificial explosion. This footage was shown, again and again, by many TV channels worldwide, and reproduced as well as in several documentary films, for instance in The Giant Buddhas, directed by Christian Frei.

Before its implementation, the Mullah's decree provoked a worldwide mobilisation and many attempts were made to convince the Taliban to call off their plans. Indeed, in February and March 2001, a quasi-universal indignation built up, in Western countries but also among 'moderate' Muslim clerics and chiefs of states outside Afghanistan. The need to preserve a cultural heritage and to respect religious tolerance was at the core of this general protest. For instance, in March 2001, The Centre Pompidou in Paris displayed on its main front a gigantic photographic reproduction ( $40 \%$ of the original statue) made from a 1887 etching. 'The picture', said the officials of the Centre, 'is a sign of protest against fanaticism, a sign of resistance to the rough demonstration of hate for differences.' Beside the procedures and steps taken by the UNESCO so as to save the statues, the MET museum (New York), as well as some Buddhist states, such as Thailand, Sri Lanka, and even Iran offered to 'buy' the Buddhas or to pay for its preservation. In vain.

Such an outrage, such an extraordinary attack on religious and cultural emblems led many to speculate about the hidden purposes of the Mullah. His argumentation and selfjustifications have been analysed endlessly.

\section{Two types of analyses}

Two categories of analyses, or of explanations, of the Mullah's astounding decision are possible. The first one, based on his and his close collaborators' explicit argumentation, highlights the Taliban clerics' conception of the Muslim law. The other category, more contextual and temporal, takes into account the general political situation. It is concerned with the position of the Taliban regime on the international scene. Though the moderate clerics and the special emissary of UNESCO brought the theological argumentation forward during their meeting with the Mullah's representatives, most of the commentators were convinced that the Mullah's decree was rather linked to the political context, to the progressive isolation of the Taliban. 
Contextual explanations are supported by the fact that the successive statements made by the Taliban since they came to power were somewhat contradictory. In July 1999, three years after the entry of the Mullah's forces in Kabul, the Taliban minister of Culture promulgated several directives insisting on the necessary protection of the antiquities and other legacies of the past. He specifically mentioned the statues of Bamiyan, pointing out that since the advent of Islam in Afghanistan, 'they never suffered any damage'. ${ }^{6}$ The minister spoke about the respect due to those antiquities and also mentioned the risk of retaliation against mosques in Buddhist countries. He made it clear that, though they were no Buddhist believers in Afghanistan, 'Bamiyan would not be destroyed but, on the contrary, protected' according to Luke Harding (2001). In comparison, the famous 26 February decree appears as a real volte-face since it maintains that 'these statues were and are sanctuary for unbelievers. These unbelievers continue to worship and to venerate these statues and pictures'?

The UNESCO emissaries pleaded in vain that a necessary distinction should be made between idolatry and exemplarity, idol and icon, between admiration and worship. It is not certain however that the Taliban made a difference between a secular admiration and an idolatrous veneration. I will go back to this point later. Others, in particular Pierre Lafrance (2001: 18), insisted on the exemplarity of piety, the 'lesson of faith', that these statues could offer to the believers of all religions. In fact, the Taliban's argumentation gave no chance of success to the ambassadors of culture. 'If the statues were objects of cult for an Afghan minority, we would have to respect their belief and its objects; but we don't have a single Buddhist in Afghanistan', said the Mullah, 'so why preserve false [sic] idols? And if they have no religious character, why get so upset? It is just a question of breaking stones' (Harding 2001). 'But why breaking stones, if they are not objects of a cult', could have answered the emissary. For the Taliban and for others, could the giant statues escape the Mullah's dilemma: could they be something else than either idol or raw stone?

Regarding the list of the outraged communities, Pierre Cambon, chief-curator of the Musée Guimet (Paris), questioned in Pour la Science (2001: 25): 'Why do they [the destroyers of the Bamiyan Buddhas] take foreign populations hostage, populations such as the people of India, of Greece, of Buddhist countries, for whom Bamiyan is, or was, the symbols of their roots and traditions? (...) Yet, how to care for the Buddhas of Bamiyan, leaving aside the general context?' This question takes us back to the second category of analyses and commentaries, which has to do with the external causes. According to most commentators, the burst of the crisis had political reasons, not theological ones; the latter being a screen for the former. The fate of the Buddhas was linked to the ostracism forced upon the Taliban regime by the members of the UNO-with the exception of Pakistan and some Arabian States.

A special report written by Asia Soura in 2008-a resource of the Asia Society (2001) enumerates five factors, which may have contributed to the Mullah's decision. The first is related to the range of UN sanctions imposed in December 2000. The second and the third factors are related to the humanitarian crisis in Afghanistan and to the offer made by western states (and, as we have seen, not only western) of substantial sums of money to protect the Buddhas, when little attention was being given to the humanitarian crisis. The fourth is the lack of reactions of the international community after Mullah Omar had banned poppy cultivation in Afghanistan, and the fifth factor is the fact that the U.N. still allowed the former Afghan President Burhanuddin Rabbani to occupy the Afghanistan 
seat at the U.N., while the Taliban's forces controlled $90 \%$ of the country. Other commentators mention a manipulation by radical elements, who wanted to make more difficult any prospect of reconciliation between the Taliban and the West. Of course, a combination of the above factors is to be taken in consideration.

It is to be noted however that Taliban officials, several times, reasserted that the Mullah's decree had 'nothing to do with the regime's craving for international recognition', as put by Mawlawi Quadratullah Jamal, Taliban minister of information and culture (Ahir 2001: 44). He added that it is totally an internal religious edict that has been excessively exaggerated in the outside world' (Ahir 2001: 51), and had 'been under consideration for six years (Ahir 2001: 53), but consequently, with the exception of 'idolaters', targeted states or institutions remain undesignated. Nevertheless, the non-explicit factors and reasons have more weight, for the commentators, than the expressed motives. The contextual factors seem to be more plausible than the theological arguments.

The humanitarian situation did trouble the western consciences. The Western World is in reality exhibiting its arrogance and its egoism, when it seems to care exclusively about salvaging the Buddhas and other antiquities, said, in substance, Paul Bernard, in Notre Histoire (2001: n. 183). Bernard, who was the head of the DAFA (Délégation Archéologique Française en Afghanistan/French Archaeological Delegation in Afghanistan) between 1964 and 1980, adds: 'The West would be ready to care for a few statues, but would remain unconcerned about the misery of the Afghan people dying of hunger!' The point was also made by Pierre Cambon (2001: 12) who wrote: 'It is dangerous to use the cultural heritage as a stake in a time of troubles; it is difficult to protect it without first taking the human needs into account.' This comment is expressed again in Christian Frei's documentary. He quotes the Iranian filmmaker Mohsen Makhmalbafi: 'I am now convinced that the Buddhist statues were not demolished. They crumbled to pieces out of shame, because of the West's indifference toward Afghanistan.' These words are controversial; the West did contribute, especially through The World Food Program, to the supplying of the Afghan population in a much bigger scale than the neighbouring states and other Middle Eastern powers. The argument was, as we have seen, used several times and with different nuances: the assault against the Buddhas was understood either as a reaction against the state of abandonment in which the West had left Afghanistan or as a kind of reprisal against the sanctions imposed by the Security Council and its refusal to recognise the Taliban Emirate.

The Taliban themselves expressed, afterwards, their indignation and anger at the protest coming from what they called the 'Christian' countries, exclusively concerned with saving 'idols' but ignorant of the ordeal endured by the Afghans. According to this point of view, it is the Afghan cultural heritage that is, itself, the hostage. It is an indirect victim of the Western countries' double standard, moved by the destruction of statues but insensible to the misery of the Afghan people. Mullah Omar and his followers actually tried to send us back to our guilty conscience. Between the humanitarian values and the cultural values, in the face of the theoretical choice between the Good and the Beautiful, the West had made the wrong choice! Unfortunately, the destruction of cultural heritage adds, in reality, and especially in Afghanistan, further to the misfortunes of the day. 


\section{People, victims, and outraged communities}

At first sight, the elimination of the statues of Bamiyan directly affects the Buddhist communities. In March 2001 already, a neo-Buddhist intellectual, Diwan Chand Ahir, originating from the Indian Dalit community, published a well-informed booklet on the destruction of the Buddhas, and on the reactions against it expressed in the Indian press. This destruction, Ahir wrote, '(...) shattered the sentiments of millions of Buddhist followers' (Ahir 2001: 57). ${ }^{8}$ Media and newspapers in Southeast Asian countries did react strongly. They portrayed themselves as the spokespersons of an outraged community as my wife and I noticed it when in Phnom Penh and Bangkok during these dramatic days of March 2001. In these Buddhist countries, the shock was much more deeply felt than in Europe and it is untrue that only an affluent West was moved at the news of the Buddhas' destruction. Yet, the emotion was different. I remember a debate that appeared in The Sunday Nation in Bangkok which, like Cambodge Soir, devoted whole pages to the fate of the Buddhas: 'The Buddha is not in his statues', said some, 'Only his teaching is important, not its material representations'. 'However', said others, 'the statues of the Buddha belong to our religious life; they are an essential aspect of the veneration of the Buddha, as an historical as well as a sacred Person.' 'As objects of art and culture, they have a material link with the teaching of the Buddha, who, ironically, finds the ultimate truth in nothingness!' concluded the newspaper. ${ }^{9}$

But, as said previously, for the Taliban and for many others, it is the Afghan people who are the true victims, not of the iconoclasm, but of the affluent countries' egoism. Even if responsible for the blowing up, the Taliban think they are right in their posture of an outraged group, outraged by the 'provocation' of these countries whose indignation and offer to pay for the preservation of the two giant figures are, in the Taliban's view, an 'unexpected moral justification', as put by Paul Bernard (2001:13).

Several shifts, or diversions, of indignation are noticeable in this display of reactions and post-factum emotions. 'Instead of lamenting over idols', said the Taliban minister for Information and Culture, 'Muslim states should get indignant about the insults against Islam' (AIDH 2001). And the minister added: 'Why didn't those Muslim clerics go to India when the Babri Mosque in Ayodha was demolished by Hindus [December 1992]?' 'Besides', he went on, 'Hindu extremists have a list with hundreds [of] other mosques to be destroyed for the same pretext'. ${ }^{10}$ 'The last thing the West would do is to protest against this demolition', the minister of Foreign Affairs adds. But on its side, The Hindu, the influential daily newspaper of South India, blamed the United States for its lack of concern about the fate of the statues of Bamiyan. The United States has other interests, The Hindu says, in connection with the oil and gas resources in this part of the world: 'Who cares for Buddha images except for a minute population of Buddhists, a handful of archaeologists, historians, art historians around the world, and the very few who bore a love for the artistic creations of mankind over the centuries?'. ${ }^{11}$

These opposite reactions demonstrate that a distinction has to be made between those who belong to the category of victim and those who belong to the outraged community: the elimination of the Buddhist images is, for the Buddhist community, an outrage while for the Taliban, the alleged lack of concern and assistance for the Afghans strengthens their position of victims. The first category is related to a material loss or damage, as well as to a moral harm that can be temporary or enduring. Hostility or discrimination, or 
both, are linked to the condition of victim. The second category is more concerned with a symbolic offence, with a sudden attack against the honour, the beliefs or the dignity of a person or of a group.

To be a victim is often a durable state that brings about socio-economical and political demand and implies a long-term strategy. Victims have a claim on those they consider responsible for their situation. Outrage can, on the other hand, arouse an immediate reaction; outraged persons or community feel forced to wash it away, just as it is necessary to purify what has been soiled.

This does not mean that victims, or supposed so, cannot also feel outraged as well: the contrast between the alleged indifference for the Afghan's plight and the sole concern for works of art was perceived as an outrage by the Taliban. Moreover, outraged communities feel victims of social or political discrimination; and victimized population are especially sensitive to outrage. So, surely, both notions are related. Yet again, the posture of the Taliban as an outraged community could be, in turn, reversed. Sheikh Yussuf Al-Qaradhaui, an authority on lawfulness and unlawfulness in Islamic law, warned for instance that 'by considering themselves more knowledgeable and more pious than the companions of the Prophet and the 'well-guided Caliphs' [the first four caliphs according to the Sunnis] who all respected historical relics, the Taliban were demonstrating impious pride' (AID 2001). The outrage, or at least the offence, did change side once more.

\section{The Hazaras, and the women of Afghanistan}

The very location of the 'outrage'-the valley of Bamiyan and its inhabitants, the Hazaras -is to be considered now. After the Communist regime collapsed in 1992, the Hazarajat, the central mountainous region of Afghanistan of which Bamiyan is the main town secured a quasi-autonomous status under the leadership of the Hezb-e Wahdat, the Party of the Unity. Bamiyan became the provincial capital of what some Hazara nationalists now call the Hazaristan-the country of the Hazaras-, a name based on the ethnic myth of a homogenous Hazara and shia community, distinct from the Afghanistan's other populations. Though they did not claim a total independence from Kabul, the Hazara leaders and the Hezb-e Wahdat set up in Bamiyan a government akin to that of an autonomous state with ministers, a parliament and an army.

Since the Islamic conquest, the site of Bamiyan, with its caves and gigantic figures, was hardly used, if not, for the former, as shelters and warehouses and, for the latter, as a reminder of idolatrous times and of idols that had been the target of past conquerors. But after 1992, and for the first time, the site and the monuments were endowed with an emblematic significance for the people of Hazarajat. For the Hazara intellectuals, the giant figures represented the ancestors of the indigenous population. They maintained that is was not accidental if the Sunni conquerors went so fiercely against their faces. In their view, the Taliban, who as Sunni and as Pashtuns are perceived as doubly hostile towards the Hazaras, could not admit this autochthonous symbol, this source of Hazara legitimacy. According to the Hazara intellectuals, this is one of the reasons why the Taliban having taken control of the Valley of Bamiyan targeted the Buddha figures. In the opinion of the Hazara elite, the destruction of the statues represented, therefore, an insult against their cultural heritage, against their dignity and against the Hazara identity. 
Let us now consider another aspect of the outrage. Soon after the Mullah's decree has been carried out, the Western press published cartoons showing the Buddhas as female silhouettes wearing a châdri, an obvious allusion to the Afghan women's condition, given that the giant figures had no face. The idea that the two Buddhas are sexually differentiated actually exists in the Afghan tradition. The $19^{\text {th }}$ century European travellers had already noticed that for the local population one of the two statues had female attributes. The inhabitants of Bamiyan indeed affirmed that the Buddhas form a couple; the taller represents the man and the 'smaller' the woman, sometimes named Lât and Manât, idols that, according to the Koran, Muhammad had been ordered to destroy. As a matter of fact, the 'little' Buddha, supposedly the female companion, had already been seriously damaged before February 2001: its head had been pulverised and a rocket fire had caused a bid hole in the lower part of the body.

It was therefore tempting to conclude that, in addition to the destruction of an idol, the Taliban wanted to mark with infamy the offending, and public, presence of a 'female' monument; as if not only the idol, but also its allegedly female component had to be neutralised. According to this 'gender'-oriented reading of the events, the fury directed against one of the Buddhas was, metaphorically, aimed at the Afghan women; it was their exclusion from the public domain and their pitiful lot during the Taliban regime that the destruction of the statues symbolically emphasized. At least from a Western point of view, Afghan women had to feel targeted and repressed in their desire of liberation.

'Shame to the West' uttered, on one side, the Taliban. 'The act committed by the Taliban is not Islamic' said, on the other side, a group of Muslim intellectuals in a statement published in the French daily Le Monde. ${ }^{12}$ Does this reciprocity in the attribution of offences means that they are equivalent? Ignorance of the other and accusation of barbarism on both sides, concludes Goody in the last chapter of Islam in Europe (2004). In reality, the British anthropologist dismisses iconoclasm of all monotheisms, of all fanaticism in time and space. In Frei's film as well, Mullah Omar's decree and its consequences are similarly downplayed: offenders and offended are exchangeable positions, iconoclasm is reduced to an opinion or a simple episode in the history of religious movements. But how valid is this relativist approach?

Yet, at the grass-root level, those who are specifically targeted or who think they are, clearly identified themselves as an outraged group changing from an imagined community to a produced and concrete one. They can feel an acute awareness of their common condition and they can react through calculated political strategies. This awareness leads to a new definition of the Self-the member of an offended communityand of the Other-the offender against whom the targeted community can be mobilised into public actions. In the case of Afghanistan, such a process happened when the Hazaras suddenly appeared as explicit actors in Afghan politics and, possibly, when Afghan women started to assert themselves as actors of the country's social life, though still timidly and still submitted to numerous constraints. The claim for rights and justice, which follow an 'outrage', as well as the condemnation of their dominated status can lead excluded groups to new forms of political assertion.

It thus appears that several human groups were affected by the Taliban's iconoclast action-an action that they perceived as an attack against their beliefs and an offence to their dignity. But in the Taliban's view, the offence was precisely these very reactions to their action while the destruction of the statues had been nothing else than the result of, 
or a tentative to erase, previous outrages. Both manipulated the issue of the Buddhas' destruction, with political aims in view: specific communities as much as Taliban.

\section{Cultural heritage or secular cult?}

In the West, the destruction of the Buddhas of Bamiyan has been condemned as an intolerable attack against the world heritage of humanity. 'The Buddhas of Bamiyan represented an unequalled cultural richness', asserts Pierre Cambon (2001: 25). Their destruction has not just affected particular 'offended communities' or 'a handful of archaeologists and art historians', as The Hindu wrote a bit too quickly. It is the whole of humanity that now mourns for one of its more precious treasures.

The making of the Afghan national heritage, with the Buddhas as its jewel, ${ }^{13}$ passed through different stages that I shall briefly address now. It is intimately related to the European venture. The first European travellers, who in the $19^{\text {th }}$ century, mentioned the gigantic figures in their travelogues, were for the most part secret agents, explorers and traffickers. The Buddhas they contemplate had no face: had they already been victims of Muslim iconoclasm? Or were the faces missing since the very building of the statues, replaced with gigantic masks that could be changed depending on the occasions? This is not known. In 1832, Alexander Burnes, an agent of the Indian Political Service, described the 'couple of idols' as relics of a past cult. He found them inelegant, even unsightly, good only for savages and their primitive beliefs (1835: 159-160).

Charles Masson, while visiting the site in 1835, was the first to recognise the effigy of the Buddha in the figures. He was also the first to admire them. He wrote: 'The traveller surveying (...) the vast and mysterious idols, and the multitude of caves around him, will scarcely fail to be absorbed in deep reflection and wonder...' (Masson 1842: 392-3). Wonder and meditation will be, from now on, the dominating feelings of the Western scholars, travellers and tourists. In the 1920s, Maurice Fouchet, ministre plénipotentiaire of France to King Amanullah, wrote: 'The Buddhas of Bamiyan are the only visible richness of Afghanistan', and he added: 'The monk philosopher, disciple of Buddha, has run away from the fanatic mullah, but the sublime stone figures still stand, arisen from faith into a superior and unknowable world, beyond the armful ignorance and the deceptive desire. Nothing, till now, could destroy these gigantic works...' (Fouchet 1931: 125-6). From the first travellers to the archaeologists, from these to the hippies of the 1970s Great Tour, all of them, or nearly all, shared the same admiration for the site. Eventually, in the 1980s, UNESCO chose the site of Bamiyan to be registered in its World Cultural Heritage's list but, because of the conflict, the registration was never officially done.

What about the Afghans? What was their feeling about the 'jewel' of their cultural heritage, this Western invention? It is difficult to know what the Buddhas meant to them. In its entry 'Bamiyân', the Qâmus-e joghrafiyâ (the geographical dictionary of Afghanistan) praised more the climate of the valley and the quality of its agricultural products than the beauties of the cliff where the Buddhas used to stand. As a matter of fact, the inhabitants of the valley used the caves to store their crop, or even as habitations. The smoke of the fireplaces had covered and damaged the frescoes located within the sanctuaries and the caves hewn in to the rock. During the recent conflict, the cavities were even used as munitions dump. 
It also has to be added that in the Muslim world, Buddha is called but, a word applied to any idol as well. Thus, for many Afghans, the two giant figures were similar to the monstrous idols mentioned in the Koran. This being said, the inhabitants of Central Afghanistan looked at the Buddhas as familiar presence and, in their religious beliefs, as survivors of the pre-Islamic time, whose pagan origins were occasionally recalled by the local mullahs. For contemporary travellers, the Buddhas of Bamiyan were no more 'active': they were not objects of veneration for Buddhist pilgrims anymore and the cliff did not shelter monks either. Religious objects previously, they were now cultural monuments, a testimony of the past. Yet, in the Taliban's view, the two Buddhas still belonged to the category of the sacred and were perceived as object of an idolatrous veneration. Were they really wrong?

In the article published in Notre histoire, Paul Bernard (2001: 12) observes that 'Art in the West has become the guardian of the value of the sacred, till now allotted to our declining religions [...] The Louvre has replaced Notre Dame.' And he goes on: 'We really feel that the destruction of the Buddhas of Bamiyan is a profanation and a sacrilege, and not only an attack against a masterpiece of Art' (2001: 13). Truly, the defenders of the cultural heritage, the UNESCO and the whole of the enlightened opinion had substituted a religion for another: they were not only offended in their veneration for Art but also, and as such, victims of a sacrilege.

In their effort to portray the cultural heritage's preservation as a human, terrestrial universal and secular value, the protestors against the destruction of the Buddhas of Bamiyan, turned it into a new transcendence; into what Frodon calls a non-religious relationship with the invisible (2002: 221) and therefore usurping, for the Taliban, what belongs to God. The indignation provoked by the destruction of a work that the West 'sacralises', as a cultural heritage of the humanity, is precisely what led the Taliban to believe that, for the West, another type of idolatry-the cult of Works of Art-has replaced the false gods of Bamiyan.

This sheds light on their complete misunderstanding of the plea presented by the Western defenders of the Buddhas: the category 'cultural heritage' hardly existed for the Taliban or was, at the best, suspicious. More vehement was the protest and more convinced were they that it only reflected a belief as illegitimate as that of idols worshippers. The Taliban's position precisely revealed their negation that a space for secular veneration could exist, wherein Art would have replaced the God of the monotheists. To worship a treasure that humanity, under numerous forms, has made and accumulated in the course of centuries could only arouse their distrust and antagonize them further.

While some were still struggling to come to term with the fact that they were loosing a valued cultural heritage, a much more extended feeling of offence was in the making. It is 'a slap for the whole humanity, for the very idea of humanity' claimed the French newspaper Libération, ${ }^{14}$ extending the outrage to an infinity. It is 'a sacrilege for humanity' declared the Indian minister of Foreign Affairs Jaswant Singh, adding to the outrage done to the cultural heritage the dimension of a desecration. The notion of sacrilege, and of the sacred, which was at the centre of the offence done to the Buddhists, was interestingly also a central component of the emotion felt much beyond the religious communities. The modern agnostics, in love with works of Art and believers in the cultural heritage of humanity, perceived themselves as the real outraged ones, even more so than the Asian Buddhists. 


\section{Conclusion: Beyond the cultural heritage}

Though an insufficient sacrifice because it came too late in their view, the Taliban ordered the destruction of the statues of Bamiyan so as to purify Afghanistan from an age-old offence. Yet, in doing so, they were also striking a blow at other convictions and their astounding act of iconoclasm led to the spiral of outrages: the offences were all linked together, they somehow answered to each other in time and space. This 'sacrifice' provoked other reactions emanating from those who considered this 'purification' nothing but a sacrilege, a sacrilege that 'has transcended the boundaries between nationalities and religions', as written in the International Herald Tribune. ${ }^{15}$ And progressively, the circle of the outraged people has considerably widened following the mobilisation of public opinion.

Would have it been conceivable to take reprisals against an attack on Art? One can admittedly makes politics with images, as Frodon asserts (2002), one could have threatened the Taliban with possible retaliatory destructions affecting fellow Muslims elsewhere, for instance. In a mail addressed to the Refugee Council online ${ }^{16}$ the $2^{\text {nd }}$ March 2001, Afghan scholars in UK suggested to mobilise Muslim minorities living in Buddhist countries against the decree: these minorities 'could appeal to Mullah Omar, arguing that this action could potentially endanger them and their relationship with Buddhists, for instance.' 'Works of art reject violence even for self-protection', Paul Bernard says in a rather angelic way, but 'At the same time, they ardently oblige us not to forget for them human misfortune', he adds (2001:13). Still, the outraged ones soon became also 'outrageurs': the mosque that supplanted the temple was destroyed in turn. ${ }^{17}$

The world-wide mobilisation against the Buddhas' destruction did not cause the foreign intervention in Autumn 2001, nor the collapse of the Taliban regime. Nevertheless, the Taliban's iconoclasm surely contributed to deligitimate their regime. The results of this process are difficult to measure, but it was indubitably efficient: it excluded from the realm of the 'civilised' humanity those who had dared to attack its 'imaginary museum'. ${ }^{18}$ The process has been all the more effective that it did not rely on any particular religious or national community but on supposedly universal values.

\section{BIBLIOGRAPHY}

Ahir, Diwan Chand (2001) Bamiyan Buddhas: Senseless Destruction by Taliban, New Delhi: Blumoon Books.

AIDH (Association Internet pour les Droits de l'Homme) (2001) Les talibans contre Bouddha, http:// www.aidh.org/Racisme/Bouddha/chronique.htm

Asia Society (2001) Taliban: What prompted Bamiyan?, Special Report, March 28, http://

www.asiasource.org/news/at_mp_02.cfm?newsid=46971

Barbier, Auguste (1840) 'Érostrate au temple d'Éphèse', Revue des Deux Mondes, tome 21. 
Bernard, Paul (2001) 'Des statues et le malheur des hommes', Notre histoire, 188, pp. 12-3.

Burnes, Alexander (1835) Travels into Bokhara, vol. 2, London: John Murray.

Cambon, Pierre (2001) 'Quand les fanatiques deviennent iconoclastes', Pour la science, 282, avril, pp. 24-5.

Centlivres, Pierre (2001) Les Bouddhas d'Afghanistan, Lausanne: Favre.

Centlivres, Pierre (2002) 'Life, Death, and Eternity of the Buddhas in Afghanistan', in Bruno Latour \& Peter Weibel (eds.), Iconoclash: Beyond the Image: Wars in Science and Religion, and Art, Cambridge, Massachusetts; Karlsruhe: Center for Art and Media, pp. 75-7.

Dupaigne, Bernard (2007) Afghanistan: Monuments millénaires, Paris: Imprimerie Nationale Éditions.

Frei, Christian (director) (2005) The Giant Buddhas, Suisse: Documentary, 35mm, 95 Min.

Frodon, Jean-Michel (2002) 'The War of Images, or the Bâmiyân Paradox', in Bruno Latour; Peter Weibel (eds.), Iconoclash: Beyond the Image-Wars in Science and Religion, and Art, Cambridge (Massachusetts); Karlsruhe: Center for Art and Media, pp. 221-3.

Fouchet, Maurice (1931) Notes sur l'Afghanistan: CEuvre posthume, Paris: Maisonneuve Frères.

Harding, Luke (2001) 'How the Buddha got his wounds', Guardian Unlimited, 3 March.

Lafrance, Pierre (2001) 'Témoignage : comment les bouddhas de Bamiyan n'ont pas été sauvés', Critique internationale, July, pp. 14-21.

Goody, Jacky (2004) Islam in Europe, Cambridge: Polity.

Goody, Jacky (2004) Islam en Europe: Histoire, échanges, conflits, Paris: La Découverte/Poche.

Masson, Charles (1842) Narrative of Various Journeys in Balochistan, Afghanistan, and the Panjab, vol. 2, London: Richard Bentley.

Peer, Basharat (2008) ‘The Long Life of the Frontier Mullah’, The Nation, 11 June.

Qâmus-e joghrafiyâ $(1335,1956-57)$ ‘Bamiyân’, Kabul.

\section{NOTES}

1. The author would like to thank Amélie Blom for her careful and pertinent rereading of the text.

2. My translation, as well as the translations of other French author's quotations.

3. According to the tradition, Erostrate set fire to the Temple at Ephesus 'to immortalise his name'!

4. Sheikh Najm ud Din, called Hadda Mullah, was an influent 'frontier mullah' who resisted the Afghan Amir Abdur Rahman (1880-1901) and fought fiercely the British, most famously in the Battle of Malakand (1897), which Churchill chronicled. The Hadda Mullah eventually died in 1903. His disciples continued to spread his influence and established numerous madrasa in eastern Afghanistan and in the North West Frontier Province (Pakistan), see also Basharat Peer (2008).

5. Associated Press. 2001. 2 March.

6. Which is far from the truth!

7. Associated Press. 2001. 26 February.

8. I thank Nicolas Jaoul, CNRS, for having put this work at my disposal.

9. The Sunday Nation. 2001. 4 March, A6. 
10. In the Times of India, Jyotirmaya Sharma puts on the same lines Mullah Omar and the Hindu extremist Kishore. 'For every Mulla Mohammad Omar in Afghanistan, there is a corresponding Giriraj Kishore. Similarly, for every felling of the Bamiyan Buddha, there is a parallel in the destruction of the Babri Masjid in India.' (Ahir 2001: 63).

11. The Hindu (Delhi edition). 2001. 16 March.

12. 9 March, 2001.

13. The 'big' one has 'precious radiant ornaments' and his 'golden complexion is bright', the 'small' one is covered with brilliant metallic plates: this is how the Chinese pilgrim Hiuan Tsang, the main authority on Bamiyan during the Buddhist period, described the two giant Buddhas in the $7^{\text {th }}$ century. Hiuan Tsang stayed in the high valley, on his way to India, in search for canonical Buddhist manuscripts in $632 \mathrm{AC}$-incidentally the year of Muhammad's death also.

14. 2 March, 2001.

15. 2 April, 2001.

16. http://www.refugeecouncil.org.uk/ accessed March 2001.

17. The Babri Mosque in Ayodha was supposedly built by order of Babur, the first Mughal Emperor, on the birthplace of the deity Rama.

18. 'Of course, all civilised people must decry and discredit the Taliban syndrome beyond our borders' (Ahir 2001: 76).

\section{ABSTRACTS}

The author analyses a rare case of mirror-outrage that followed the destruction of the Buddhas of Bamiyan. This event brought the Taliban and the international community into opposition in 2001. The article first stresses the intriguing paradigmatic similarities between the destruction of the Buddhas and the destruction of Artemis Temple in $356 \mathrm{BC}$, when the eradication of a monument, sacred as well as emblematic of a cultural heritage, was perceived as an outrage against piety and beauty. This analogy helps the author emphasize the uncertainty regarding the identification of the victims: were they 'the people' in general, abstract deities, or specific communities? The article then elaborates on the argumentation and self-justification presented by the Taliban, and underlies their sense of indignation at a protest coming from 'Christian' countries, which they saw as exclusively concerned with saving 'idols' but ignorant of the ordeal endured by the Afghans. It finally argues that conflicting visions over the very meaning of 'cultural heritage' were at the core of the controversy. 